\title{
A study of associations between gastric ulcers and the behaviour of finisher pigs
}

Rutherford, Kenneth M.D.; Thompson, Carol S.; Thomson, Jill R.; Lawrence, Alistair B.; Nielsen, Elisabeth O.; Busch, M. Erika; Haugegaard, Svend; Sandøe, Peter

Published in:

Livestock Science

DOI:

10.1016/j.livsci.2018.03.013

Publication date:

2018

Document version

Peer reviewed version

Document license:

CC BY-NC-ND

Citation for published version (APA):

Rutherford, K. M. D., Thompson, C. S., Thomson, J. R., Lawrence, A. B., Nielsen, E. O., Busch, M. E., Haugegaard, S., \& Sandøe, P. (2018). A study of associations between gastric ulcers and the behaviour of finisher pigs. Livestock Science, 212, 45-51. https://doi.org/10.1016/j.livsci.2018.03.013 


\section{A study of associations between gastric ulcers and the behaviour of finisher pigs ${ }^{1}$}

Kenneth M. D. Rutherford ${ }^{\mathrm{a},{ }^{*}}$, Carol S. Thompson ${ }^{\mathrm{a}}$, Jill R. Thomson ${ }^{\mathrm{b}}$, Alistair B. Lawrence ${ }^{\mathrm{a}}$, Elisabeth O. Nielsen ${ }^{\text {c,\#}, ~ M . ~ E r i k a ~ B u s c h ~}{ }^{c \S}$, Svend Haugegaard ${ }^{c}$, Peter Sandøe ${ }^{\mathrm{d}}$

a. Animal Behaviour and Welfare, Animal and Veterinary Sciences Research Group, SRUC, West Mains Road, Edinburgh EH9 3JG, Scotland

b. SAC Consulting, Veterinary Services, Bush Estate, Penicuik EH26 0QE,Scotland

c. Danish Agriculture \& Food Council, SEGES, Axelborg, Axeltorv 3, DK-1609 Copenhagen, Denmark

d. Department of Food and Resource Economics and Department of Veterinary and Animal Sciences, University of Copenhagen, Rolighedsvej 25, DK-1958 Frederiksberg C, Denmark

Email addresses: Kenny.Rutherford@sruc.ac.uk; Carol.Thompson@sruc.ac.uk; Jill.Thomson@sac.co.uk; Alistair.Lawrence@sruc.ac.uk; ELONI@,fvst.dk; dkmaer@,chrhansen.com; sud@seges.dk; SVH@seges.dk; pes@sund.ku.dk

* Corresponding author: Animal Behaviour and Welfare, Animal and Veterinary Sciences Research Group, SRUC, West Mains Road, Edinburgh EH9 3JG, Scotland

\# Present address: Danish Veterinary and Food Administration, Stationsparken 31-33, 2600 Glostrup, Denmark

§ Present address: Chr. Hansen Ltd., Bøge Allé 10-12, 2970 Hørsholm, Denmark

\footnotetext{
${ }^{1}$ The reference of the printed version is:

Rutherford KMD, Thompson CS, Thomson JR, Lawrence AB, Nielsen EO, Busch ME, Haugegaard S, Sandøe P. (2018). A study of associations between gastric ulcers and the behaviour of finisher pigs. Livestock Science 212: 45-51.

The definitive version is available at

https://doi.org/10.1016/j.livsci.2018.03.013
} 


\begin{abstract}
Gastric ulcers are a common condition in finisher pigs. A study was conducted to investigate the hypothesis that gastric ulceration alters the behaviour of finisher pigs. Two one-hour observations (from video recordings) of home pen behaviour were conducted in finisher pigs, at two farms (one in Denmark and one in Scotland), in the days immediately prior to slaughter. Stomach condition was assessed post mortem according to a pre-established ulcer score index. The behaviour of pigs with healthy stomachs $(n=36)$ was compared with the behaviour of pigs with deep ulceration of the pars oesophagea $(n=26)$. Assessment of various predefined postures and behaviours was made by an observer blind to the gastric ulcer status of the observed pigs. Behavioural data from the two sites were combined in a single analysis. Pigs with gastric ulcers tended to spend less time idle $(\mathrm{P}=0.081)$ and less time lying on their left side $(\mathrm{P}=0.064)$, and significantly more time standing $(\mathrm{P}=0.009)$, or walking $(\mathrm{P}=0.038)$ compared to healthy pigs. Pigs with ulcers also showed an increased frequency of posture changes $(\mathrm{P}=0.02)$. A decrease in time spent lying on the left and an increase in standing/walking could both be interpreted as attempts to avoid liquid gastric contents pooling in the cranial region of the stomach. This along with the higher level of posture changes observed may indicate some degree of pain/discomfort associated with the presence of gastric ulcers in pigs. This study is the first to identify apparent behavioural differences between finisher pigs with or without gastric ulcers, and further work is needed to establish to what extent the apparent behavioural differences are a consequence of pain or discomfort for the animals concerned. Since gastrooesophageal ulceration of pigs is associated with pelleting and fine grinding of feed which in turn is linked to increased growth efficiency there may be a dilemma between on one hand concern for preventing gastric ulcers and on the other hand concern for the efficiency and sustainability of pig production.
\end{abstract}

Keywords: Gastric ulcer; Pigs; Behaviour; Welfare

\title{
1. Introduction
}

The occurrence of gastric ulcers in pigs is an on-going concern in relation to animal health and production. Erosion and ulceration of the lining of the stomach is a common condition in intensively managed pigs (Thomson and Friendship, 2012). It occurs around the area where the oesophagus enters the stomach (called the pars oesophagea). In the early stages of the disease, the pars oesophagea becomes roughened and gradually changes as the surface becomes eroded and can get deeply ulcerated (Doster, 2000). These changes may lead to intermittent haemorrhage followed by anaemia, or massive haemorrhage resulting in death.

The prevalence of gastric lesions in pigs is a major cause for concern in many pig producing countries (and has been for many decades: Baustad and Nafstad, 1969). A recent abattoir study in the UK (Swaby and Gregory, 2012) found that four out of every five slaughter pigs had some signs of ulceration or pre-ulcerative damage, and $6 \%$ of slaughter pigs had signs of severe 
ulceration. A study examining 1101 finisher pigs in Denmark found that 29\% had signs of moderate to severe ulceration (Nielsen et al. 2012). Similarly, high gastric ulcer prevalences have been found in a number of countries over the last two decades (Thomson and Friendship, 2012). The prevalence of ulcers seen at slaughter can be highly variable between farms (Christensen and Cullinane, 1990; Guise et al. 1997), and on-farm mortality associated with bleeding from ulcers can be high on affected units (Melnichouk, 2002).

The pathogenesis of gastric ulcers appears to be highly multifactorial. The incidence and severity of the condition are associated with nutritional factors, housing and feeding systems, some forms of stress, pig gender, other concurrent diseases and genetic effects (Doster, 2000; Thomson and Friendship, 2012). However, amongst these the physical structure of feed is the most significant risk factor; fine particle size and pelleting significantly increase the prevalence of gastric ulcers (Wondra et al. 1995; Eisemann and Argenzio, 1999b; Robertson et al. 2002; Grosse Liesner et al. 2008; Millet et al. 2012a, 2012b; Cappai et al. 2013; Mösseler et al. 2014; Overholt et al. 2016). It is thought that the more fluid gastric contents associated with these feeds allow reflux of acidic fluids to the non-glandular tissue of the pars oesophagea.

Whilst the incidence of gastric ulcers is high in commercial pigs and the pathology well recognised, there appears to be little information as to how the condition affects welfare. A small proportion of pigs with severe acute ulcers hemorrhage either die on farm (e.g. Melnichouk, 2002) or show various acute clinical signs of pain (Taylor, 2006), and perforation of an ulcer can also lead to peritonitis (Jackson and Cockcroft, 2007). Such animals clearly suffer impairment to their welfare. However, the majority of pigs with gastric ulcers are not detected under farm conditions, and the welfare status of these sub-clinically affected animals relative to those with healthy stomachs remains uncertain. Finding out whether these ulcerated pigs suffer is important because the main risk factor for ulceration (the feeding of pelleted feed with small particle size) is used by the industry to improve feed conversion efficiency. So the clear benefits in terms of production efficiency (Doster, 2000) of this feeding strategy need to be balanced against any detrimental effect to welfare; and if there were significant effects on welfare would it would seem relevant to consider changing this strategy.

To date no scientific appraisals have been made of the welfare significance of gastric ulcers in pigs. Whilst it might be presumed that ulcers, at least beyond a certain level of severity, have a negative effect on welfare, the extent of this effect has not been quantified. Since behavioural indicators are widely used in the study of pain in pigs (Ison et al. 2016) and as a first step towards understanding the welfare impact of gastric ulcers, the aim of the present study was to conduct a controlled study of the behaviour of pigs with and without ulcers.

\section{Materials and Methods}

Video footage was collected and analysed from pigs at two different research farms: Grønhøj (GR) farm in Denmark and EasterHowgate (EH) farm in Scotland. Video recordings were 
taken from all study pigs, and healthy or ulcerated pigs were retrospectively chosen for detailed behavioural analysis based on post mortem appraisal of stomach condition. The experiments at both farms were conducted in accordance with EU Directive 2010/63/EU and following ethical review by SRUC's Animal Welfare and Ethical Review Body, and the Scottish study was conducted under UK Home office licence.

\subsection{Grønhøj farm, Denmark}

The pigs used in this study were part of a larger study, which aimed to investigate the performance and health implications of gastric ulcers in pigs. In each replicate (batch) of the study, pigs (Dam: DanAvl landrace + DanAvl Yorkshire; Sire: DanAvl Duroc) were housed, from $30 \mathrm{~kg}$, in 10 pens $(4.33 \mathrm{~m} \times 2.75 \mathrm{~m}$; two thirds slatted flooring), with 12 pigs (females and barrows) in each pen. Before the trial started, weaners to be included in the trial were fed medium-coarse meal feed. During the trial period pigs were ad libitum fed a pelleted feed from a single electronic feeder (NEDAP, The Netherlands) in each pen. Each pen also had a single drinker and an enrichment device (a vertical wooden log attached to the side of the pen). The pigs were tagged with electronic ear tags (for identification by the feeding system) and were spray marked with an identification system based on stripes, which allowed individual pigs in each group to be identified on video. Lights were on in the experimental building from 0500 to 2100 .

Video recordings were made from single cameras positioned above each pen. Footage was recorded onto a digital system (AnnoxNext). The pigs selected for observation came from four separate batches of a larger trial. On the day of slaughter, pigs were transported (for $\sim 1$ hour) to a commercial abattoir, and kept in lairage for $\sim 1$ hour before slaughter. Stomachs were collected, marked with pig identification and transported to the Danish Laboratory for Pig Diseases for assessment.

\subsection{EasterHowgate Farm, Scotland}

Seventy-eight pigs (Dam: Large White $\mathrm{x}$ Landrace, Sire: Hampshire) were used in two separate batches of 39 pigs. Pigs were housed (from $\sim 2$ weeks prior to slaughter) in small $(2.85 \mathrm{~m} \mathrm{x}$ $3.7 \mathrm{~m}$ for a single pen) straw bedded pens, with ad libitum access to a pelleted feed in a trough (DIMENSIONS) and a single drinker in the pen. Each pen held between 3 and 6 pigs (pens with 4, 5 or 6 pigs were provided with twice as much space as the groups of 3 ). Lighting was on between 0600 and 1800 .

Video recordings were made from single cameras positioned above each pen. Footage was recorded onto a digital system (GeoVision). Prior to moving to the experimental building, pigs had been housed from weaning onwards in larger pens with straw bedding in groups of between 10 and 20 pigs. Pigs were euthanized on-site at $\mathrm{EH}$. On the day of euthanasia, pigs were moved in their whole groups to a different pen. Feed was provided in the home pen until 
each group was moved for euthanasia. Individual pigs were then sedated before being given an overdose of barbiturates (Euthatal) via injection to the heart. Following confirmation of death, stomachs were dissected out whole and transferred to the SAC Consulting Veterinary Services (SACCVS) for gastric ulcer scoring.

\subsection{Ulcer scoring and selection of pigs for observation}

Stomachs were scored according to a pre-existing gastric ulcer scoring system (Jensen et al. 2017; Table 1) at the Danish Laboratory for Pig Diseases or at SACCVS by experienced veterinary pathologists. The non-glandular pars oesophagea ('white part') of each stomach was scored for the presence of hyperkeratosis (where the mucosa of the pars oesophagea has become thickened and keratinized), erosion (superficial tissue erosion where layers of the epithelium have disappeared but the basement membrane is intact), ulceration (where the submucosa, nerves and blood vessels are exposed and potentially damaged) and scarring or stenosis of the oesophageal opening. The final ulcer score (ranging from 0 to 10) for any individual stomach is based on the severity of the most severe sign seen (e.g. an erosion score of 1 produces a stomach index score of 4 , irrespective of how much hyperkeratosis is present). Based on the stomach score, individual pigs were retrospectively chosen for behavioural analysis (healthy: score 0 or 1; gastric ulcer: score 7 or 8, i.e. 'deep' rather than 'superficial' (score 6) lesions). In the scoring system a stomach can be given a score of 6, 7, or 8 based on the presence and extent of an ulcer, or based on the presence of scar tissue. All selected ulcerated GR pigs had an ulcer (i.e. any pigs which were scored 7 or 8 due to scarring alone were not considered for selection) but all also had signs of scarring from healing or healed ulcers. All ulcerated EH pigs only had ulcers without any distinguishable scar tissue. Pigs recorded with other health problems (at slaughter or earlier in the trial) were excluded from selection, and selection of pigs for observation was done blind to pig sex or weight. One experimenter identified a complete list of possible observation pigs, and this list (blinded to gastric ulcer status) was passed onto another experimenter who conducted preliminary observations of the relevant recordings to identify and rule out pigs that were not visible for the majority of the required observation time. This meant that some healthy or ulcerated pigs in the trial could not be observed. Under these criteria, observations were conducted on 40 pigs at GR (mean \pm SE weight: $85.2 \mathrm{~kg} \pm 1.36 ; 22$ females, 18 castrated males; 13 pigs (healthy: 7, gastric ulcer: 6) from batch one, 21 (healthy: 12, gastric ulcer: 9) from batch two, three (healthy: 1, gastric ulcer: 2) from batch three, three (healthy: 1, gastric ulcer: 2) from batch four) and 22 pigs at $\mathrm{EH}$ (mean $\pm \mathrm{SE}$ weight: 114.6kg $\pm 2.8 ; 16$ females, 6 males; 12 (healthy: 7, gastric ulcer: 5) from batch one and 10 (healthy: 8 , gastric ulcer: 2) from batch two).

\subsection{Behavioural analysis}

Quantification of different behavioural states and events was conducted using Observer Software (Noldus, Version 12.5). Two one-hour long continuous focal observations were conducted on video recordings of 36 healthy pigs and 26 pigs with gastric ulcers $(\mathrm{GR}: \mathrm{n}=21$ 
healthy, 19 ulcerated; EH: n=15 healthy, 7 ulcerated). All behavioural observations were conducted by a researcher who was blind to the gastric ulcer status of individual observed pigs. Intra-observer testing was conducted at the mid-point of the observations to ensure reliability. The timing of the two one-hour long observations differed between EH and GR. For the GR pigs observations were conducted on video footage recorded between 0800 and 0900 and between 1600 and 1700 on the day prior to slaughter. EH observations were conducted on footage recorded either one or two days prior to slaughter. The first observation was the last hour before farm staff entered the room to check pigs and muck out pens (approximately between 0600 and 0700). The second observation started between 0930 and 1030 for different pens. The ethogram (Table 2) was developed based on previous work (D'Eath, 2002; Rutherford et al. 2006; Camerlink and Turner, 2013; Hintze et al. 2013; Ison et al. 2016) and on preliminary viewings of a selection of recordings.

\subsection{Statistical analysis}

All analysis was conducted in Genstat (16 ${ }^{\text {th }}$ Edition) using the REML procedure. Initial models (analysing the two sites separately) fitted gastric ulcer status (scores 7 or $8=$ yes; scores 0 or $1=$ no), time (first or second observation) and sex as fixed effects, and pig weight as a covariate. Observation time did not prove significant alone or in interaction with treatment so subsequent analysis were conducted on datasets which combined the two one-hour observations. For initial models the random effect was pig nested within batch/pen (a single variable produced from each unique combination of batch and pen), and for the subsequent analyses it was batch/pen. Initial models examined interaction effects. Where effects of sex or weight were not found, these parameters were removed from the model. Data were transformed where necessary to achieve normality of residuals. Final models were run which included data from both sites and followed the same process as that described here for the single site analyses (but with site fitted as a fixed effect). Many of the behavioural states did not occur often enough to analyse; only four states were included in statistical analysis: idle, nosing other pigs, feeding (GR: being in the feeder; EH: with the head in the feed trough) and rooting/exploring the pen. For the behavioural events, individual events, with the exception of Ease Quarters Hind, occurred too infrequently to analyse, so the behavioural events were summed either according to whether they were front leg events, rear leg events, or as a total of all recorded events.

\section{Results}

\subsection{GH pigs}

The prevalence of gastric ulcers was low in batch 1 but increased in subsequent batches (Table 3). Gastric ulcer status did not significantly affect any of the posture variables, apart from a trend towards increased time spent kneeling/sitting in pigs with ulcers (Table 4). For the four behavioural states recorded, there were also no significant effects, apart from a trend for 
increased time spent nosing other pigs in pigs with ulcers (Table 5). There were no differences between pigs with and without ulcer in the recorded behavioural events (Table 5).

\subsection{EH pigs}

The distribution of gastric ulcer scores seen in the EH pigs is shown in Table 3. The total frequency of posture changes or duration spent lying on the right hand side, ventral lying, mixed lying, kneeling/sitting or walking did not differ between pigs with and without ulcers (Table 4). The duration of time spent lying on the left side was significantly lower in pigs with ulcers (Table 4). Pigs with ulcers also spent significantly more time standing (Table 4). There were no significant differences between pigs with and without ulcers in any of the four behavioural states or in the behavioural events (Table 5).

\subsection{Combined analysis}

When data from both sites were combined in a single analysis, three posture variables showed significant differences between pigs with and without gastric ulcers. Pigs with ulcers spent longer standing or walking, and showed a higher frequency of posture changes than pigs without ulcers (Table 4). There was also a trend for pigs with ulcers to spend less time lying on their left side. The only significant effect of site was on duration of rooting/exploring; this behaviour was much more common at EH compared to GR (Duration in seconds, Predicted Mean $\pm \mathrm{SE}: \mathrm{EH}=832.6 \pm 112.7 ; \mathrm{GR}=30.8 \pm 106.9$ ). The four behavioural states did not differ significantly according to ulcer status, though there was a trend for less time spent idle in pigs with an ulcer compared to those without (Table 5). There was no effect of ulcer status on the individual behavioural events recorded or on the total number of events seen (Table 5).

\section{Discussion}

Gastric ulcers, in finisher pigs and sows, occur at high prevalence in many countries with an intensive pig industry (e.g. Swaby and Gregory, 2012). The main risk factors for gastric ulcers are well known but many are an inherent part of modern efficient pig production. There is potentially a relationship between increased feed efficiency (by using pelleted feed with a small particle size; e.g. $<700 \mu \mathrm{m}$ : Cappai et al. 2013) and increased ulceration that may give rise to a dilemma between sustainability and prevention of gastric ulcers. However, the welfare implications of gastric ulcers are unclear. Studies on growth rates in ulcerated pigs have produced variable findings (Thomson and Friendship, 2012), and no detailed attempts have been made to assess behavioural or physiological measures, which might reflect the welfare status of affected animals. Given this, it is not clear to what extent the pig industry or the public should be concerned about stomach ulcers. As a first step to understand the link between gastric ulcers and animal welfare his study aimed to compare the behaviour of pigs with and without deep gastric ulcers. 
No association was found between the presence of gastric ulcers and various specific pig behaviours recorded at the two sites. However, at EH, pigs with ulcers were found to spend more time standing and less time lying on their left side compared to pigs with healthy stomachs. The same pattern (decreased left lateral lying and increased standing) was seen in the GR pigs, but the difference between pigs with and without gastric ulcers did not reach statistical significance. When data from EH and GR were combined into a single analysis the duration of standing and walking were found to be higher in pigs with ulcers, and these pigs also showed a higher overall frequency of posture changes. There was a trend for pigs with ulcers to spend less time lying on their left side.

It is worth considering, provided the direction of causality is that gastric ulcers cause the change in behaviour, why that might be the case. Within the abdominal cavity the stomach sits largely to the left of the medial line, though the pars oesophagea and the nonglandular mucosa, which is the site of ulceration when it occurs, sit more centrally. It is possible to speculate that lying on the left may either: i) increase exposure of the pars oesophagea to gastric fluids, or ii) increase physical pressure on the damaged tissue (for instance, from the pressure of the liver now being above it). Lying on the left makes the ingesta (if liquid) go into the cardiac portion of the stomach, so is likely to keep the ingesta in contact with the oesophageal area. Lying on the right makes the ingesta go into the fundic and pyloric areas of the stomach, away from the oesophageal area. A tendency for decreased time lying on the left side in pigs with ulcers might therefore imply that having acidic material in contact with ulcerated tissue is painful. The other behavioural differences - increased time standing and increased restlessness (as indicated by the frequency of postural changes) - also tentatively suggest the presence of some pain or discomfort associated with gastric ulceration. A study of shoulder ulcers in pigs (Larsen et al. 2015) similarly found an increased standing time in pigs with shoulder ulcers, as well as other changes such as increased frequency of overall posture changes, and concluded these were pain related.

In comparison to somatic pain, visceral pain has a number of distinctive defining features. It is diffuse and poorly localised within the body (Cervero and Laird, 1999), which means that behavioural responses tend to be less specific and whole-body responses are more common (Sikandar and Dickenson, 2012). Visceral pain is also given higher affective-motivational pain ratings by human patients (i.e. visceral pain is more emotionally distressing) (Sikandar and Dickenson, 2012) and commonly induces increased anxiety/fear in animal models (e.g. Zhang et al 2014). With reference to pigs, the diffuse nature of visceral pain could explain the general (i.e. not focused on a particular body region) behavioural differences seen in pigs with gastric ulcers. In addition to spontaneous pain, visceral pain can also alter somatic sensitivity causing referred hyperalgesia (Traub and Wang, 2004; Yarushkina et al. 2006). For instance, rats with induced gastric ulcers were found to have a lower nociceptive response threshold to thermal stimulation of the tail (Yarushkina et al. 2006). Indeed, Taylor (2006) reports that pigs with acute gastric ulcers are more sensitive to pressure applied to the xiphoid process. Farmers rate gastrointestinal disease as being similarly painful as lameness and shoulder ulcers; 
gastrointestinal disease was given a mean rating of 5.6 out of 10 for painfulness by pig farmers, compared to a score of 6.3 for lameness (a pig with minimal ability to bear weight) and 5.6 for shoulder sores (Ison and Rutherford, 2014).

It is of course possible that the link between lesion status and behaviour could causally occur in either direction. For instance, it is not possible to rule out the possibility that pig behaviour can be a risk factor for gastric ulcer formation (and therefore that the differences in behaviour between pigs with and without ulcers were pre-existing and in some sense relate to why ulcers subsequently formed; e.g. that restless pigs could be more likely to get ulcers). Indeed, previous studies have found that coping style can affect the susceptibility of pigs to develop ulcers (Hessing et al. 1994; Bolhuis et al. 2006) so behavioural risk factors are plausible.

The issue of feeding and gastric ulceration in pigs is an interesting example where there may be trade-offs between different desirable and undesirable aspects of production. Pelleting and fine grinding of feed (the principal risk factors for ulceration) have various apparent positive effects: increased performance (Eisemann and Argenzio, 1999a; Mikkelsen et al. 2004; Millet et al. 2012b; Ball et al. 2015; Nemechek et al. 2015; Overholt et al. 2016); reduced nitrogen excretion (Wondra et al. 1995; Ball et al. 2015); reduced greenhouse gas emissions (Dammgen et al. 2016); reduced feed wastage (Ball et al. 2015). These effects are linked to increased efficiency and increased sustainability (smaller negative effects on the environment and the climate per $\mathrm{kg}$ pork produced). There are also likely negative effects: poor environmental conditions for pigs and stock workers (e.g. increased particulate matter in pig houses: Ulens et al. 2015); negative alterations to gut health (Eisemann and Argenzio, 1999b; Sander et al. 2012; Longpré et al. 2016) and increased food safety risk (Mikkelsen et al. 2004; Hedemann et al. 2005; Visscher et al. 2009). Gastric ulceration also raises animal welfare concerns; certainly for animals that haemorrhage and die, and perhaps, as suggested here, an effect of ulceration on pig discomfort. However, further studies are needed to properly investigate the full animal welfare significance of gastric ulcers before the issue of how to deal with competing concerns can fully be addressed. These studies should attempt to confirm the behavioural associations identified here and should expand the behavioural assessment to consider the motivational significance of pain putatively associated with ulcers. They should also investigate the effects of pain relief provision and add assessment of physiological variables in order to fully understand the welfare relevance of gastric ulceration.

\section{Conclusion}

The study demonstrated behavioural differences - alterations to postural time budgets and an increased frequency of posture changes - between pigs with and without gastric ulcers. The most plausible explanation for these effects is that sub-clinical ulceration may cause pigs to experience some degree of discomfort. However, other explanations are possible, and the failure to fully replicate findings across the two studies does indicate that a note of caution is 
warranted. The behavioural differences between pigs with and without ulcers are also difficult to classify in terms of the severity of any welfare impact associated with them.

\section{Acknowledgements}

Funding from SEGES, Danish Pig Research Centre supported this study. This funding is mainly from pig industry sources, and three of the authors of the paper also work for, or have worked for, this organisation, resulting in a potential or perceived conflict of interest. However, the contract for this research with two of the independent academic partners (SRUC and University of Copenhagen) explicitly endorses that the work is at 'arm's length' from commercial interests, and the first and senior author, who work with the two academic partners, have led the process, and are satisfied that the framing of the study and the interpretation of the findings have not been unduly influenced by commercial interests.

Thanks to Per Mark Hagelskjær and the Grønhøj farm staff for animal care and organisation of marking pigs and collection of video footage at Grønhøj. Thanks to Jo Donbavand and Mhairi Jack for animal care at EasterHowgate and for assistance with pig euthanasia and tissue collection. Agnieszka Futro and Marianne Farish also provided help with pig euthanasia and tissue collection. Thanks also to the EasterHowgate farm staff (Peter Finnie, Phil O'Neil) for animal care during the pilot trial. Thanks to Calum Wilson at SACCVS and to Jens-Ove Hansen (JOH Consult) for assistance with stomach tissue collection and processing for ulcer scoring. Thanks to Kenneth Damholt Kristensen (Denmark) and Tomasz Krzyzelewski (Scotland) for assistance with transfer of the video files.

\section{References}

Ball, M. E. E., Magowan, E., McCracken, K. J., Beattie, V. E., Bradford, R., Thompson, A., Gordon, F. J., 2015. An investigation into the effect of dietary particle size and pelleting of diets for finishing pigs. Livest. Sci. 173, 48-54.

Baustad, B., Nafstad, I., 1969. Gastric ulcers in swine 4. Effects of dietary particle size and crude fiber contents on ulceration. Pathol. Vet. 6, 546-556.

Bolhuis, J. E., Schouten, W. G. P., Schrama, J. W., Wiegant, V. M., 2006. Effects of rearing and housing environment on behaviour and performance of pigs with different coping characteristics. Appl. Anim. Behav. Sci. 101, 68-85.

Camerlink, I., Turner, S. P., 2013. The pig's nose and its role in dominance relationships and harmful behaviour. Appl. Anim. Behav. Sci. 145, 84-91.

Cappai, M. G., Picciau, M., Pinna, W., 2013. Ulcerogenic risk assessment of diets for pigs in relation to gastric lesions prevalence. BMC Vet. Res. 9:36.

Cervero, F. \& Laird, J. M., 1999. Visceral pain. Lancet 19, 2145-2148.

Christensen, N. H., Cullinane, L. C., 1990. Monitoring the health of pigs in New Zealand abattoirs. New Zeal. Vet. J. 38, 136-141. 
D'Eath, R. B., 2002. Individual aggressiveness measured in a resident-intruder test predicts the persistence of aggressive behaviour and weight gain of young pigs after mixing. Appl. Anim. Behav. Sci. 77, 267-283.

Dammgen, U., Liermann, W., Boschen, V., Berk, A., Danicke, S., 2016. The effect of feed conditioning and composition on greenhouse gas and ammonia emissions from fattening pigs and broilers along the entire production chain. Landbauforschung 66, 45-69.

Doster, A. R., 2000. Porcine gastric ulcer. Vet. Clin N. Am-Food A., 163-174.

Eisemann, J. H., Argenzio, R. A., 1999a. Effects of diet and housing density on growth and stomach morphology in pigs. J. Anim. Sci. 77, 2709-2714

Eisemann, J. H., Argenzio, R. A., 1999b. Effects of diets differing in propensity to promote gastric lesions on defense systems in gastric mucosae. J. Anim. Sci. 77, 2715-2720.

Grosse Liesner, V., Taube, V., Leonhard-Marek, S., Beineke, A., Kamphues, J., 2008. Integrity of gastric mucosa in reared piglets - effects of physical form of diets (meal/pellets), pre-processing grinding (course/fine) and addition of lignocellulose (o/2.5\%). J. Anim. Physiol. An. N. 93, 373-380.

Hedemann, M. S., Mikkelsen, L. L., Naughton, P. J., Jensen, B. B., 2005. Effect of feed particle size and feed processing on morphological characteristics in the small and large intestine of pigs and on adhesion of Salmonella enterica serovar Typhimurium DT12 in the ileum in vitro. J. Anim. Sci. 83, 1554-1562.

Herskin, M. S., Jensen, H. E., Jespersen, A., Forkman, B., Jensen, M. B., Canibe, N., Pedersen, L. J., 2016. Impact of the amount of straw provided to pigs kept in intensive production conditions on the occurrence and severity of gastric ulceration at slaughter. Res. Vet. Sci. 104, 200-206.

Hessing, M. J. C., Schouten, W. G .P.,Wiepkema, P. R., Tielen, M. J. M., 1994. Implications of individual behavioral characteristics on performance in pigs. Livest. Prod. Sci. 40, 187196.

Hintze, S. Scott, D. Turner, S. Meddle, S. L., D'Eath, R. B., 2013. Mounting behaviour in finishing pigs: Stable individual differences are not due to dominance or stage of sexual development. Appl. Anim. Behav. Sci. 147, 69-80.

Ison, S. H., Rutherford, K. M. D., 2014. Attitudes of farmers and veterinarians towards pain and the use of pain relief in pigs. Vet. J. 202, 622-627.

Ison, S. H., Di Giminiani, P. Clutton, R. E., Rutherford, K. M. D. 2016. A review of pain assessment in pigs. Front. Vet. Sci. 3: 108

Ison, S. H., Jarvis, S., Rutherford, K. M. D., 2016 The identification of potential behavioural indicators of pain in periparturient sows. Res. Vet. Sci. 109, 114-120.

Jackson, P. G. G., Cockcroft, P. D., 2007. Handbook of pig medicine. Saunders, London

Jensen, K. H., Jørgensen, E., Haugegaard, S., Herskin, M. S., Jensen, M. B., Pedersen, L. J., Canibe, N., 2017. The dose-response relationship between the amount of straw provided on the floor and gastric ulceration of pars oesophagea in growing pigs. Res. Vet. Sci. 112, 6674.

Larsen, T., Kaiser, M., Herskin, M. S., 2015. Does the presence of shoulder ulcers affect the behaviour of sows? Res. Vet. Sci. 98, 19-24. 
Longpré, J., Fairbrother, J. M., Fravalo, P., Arsenault, J., LeBel, P., Laplante, B., Surprenant, C., Massé, D., Letellier, A., 2016. Impact of mash feeding versus pellets on propionic/butyric acid levels and on total Escherichia coli load in the gastrointestinal tract of growing pigs. J. Anim. Sci. 94, 1053-1063.

Melnichouk, S. I., 2002. Mortality associated with gastric ulceration in swine. Can. Vet. J. 43, 223-225.

Mikkelsen, L. L., Naughton, P. J., Hedemann, M. S., Jensen, B. B., 2004. Effects of physical properties of feed on microbial ecology and survival of Salmonella enterica Serovar Typhimurium in the pig gastrointestinal tract. Appl. Environ. Microb. 70, 3485-3492.

Millet, S., Kumar, S., De Boever, J., Ducatelle, R., De Brabander, D., 2012a. Effect of feed processing on growth performance and gastric mucosa integrity in pigs from weaning until slaughter. Anim. Feed Sci. Tech. 175, 175-181.

Millet, S., Kumar, S., De Boever, J., Meyns, T., Aluwé, M. De Brabander, D., Ducatelle, R., $2012 \mathrm{~b}$. Effect of particle size distribution and dietary crude protein content on growth performance and gastric mucosa integrity of growing-finishing pigs. Vet. J. 192, 316-321.

Mösseler, A. K., Wintermann, M. F., Beyerbach, M., Kamphues, J., 2014. Effects of grinding intensity and pelleting of the diet - fed either dry or liquid - on intragastric milieu, gastric lesions and performance of swine. Anim. Feed Sci. Tech. 194, 113-120.

Nemechek, J. E., Tokach, M. D., Dritz, S. S., Goodband, R. D., DeRouchey, J. M., Woodworth, J. C., 2015. Effects of diet form and type on growth performance, carcass yield, and iodine value of finishing pigs. J. Anim. Sci. 93, 4486-4499.

Nielsen, E. O., Haugegaard, S., Jørgensen, L., 2012. Prevalence of stomach ulcers in Danish sows and finishers. International Pig Veterinary Society Congress 2012, p240.

Overholt, M. F., Lowell, J. E., Arkfeld, E. K., Grossman, I. M., Stein, H. H., Dilger, A. C., Boler, D. D., 2016. Effects of pelleting diets without or with distillers' dried grains with solubles on growth performance, carcass characteristics, and gastrointestinal weights of growing-finishing barrows and gilts. J. Anim. Sci. 94, 2172-2183.

Robertson, I. D., Accioly, J. M., Moore, K. M., Driesen, S. J., Pethick, D. W., Hampson, D. J., 2002. Risk factors for gastric ulcers in Australian pigs at slaughter. Prev. Vet. Med. 53, 293-303.

Rutherford, K. M. D., Haskell, M. J., Glasbey, C., Lawrence, A. B., 2006. The responses of growing pigs to a chronic-intermittent stress treatment. Physiol. Behav. 89, 670-680.

Sander, S. J., Bullermann, J., Arlinghaus, M., Verspohl, J., Kamphues, J., 2012. The influence of grinding intensity and compaction of diets on the microbial community in the gastrointestinal tract of young pigs. J. Anim. Sci. 90, 16-18.

Sikandar, S., Dickenson, A. H., 2012. Visceral pain - the ins and outs, the ups and downs. Current Opinion in Support and Palliative Care 6, 17-26.

Swaby, H., Gregory, N. G., 2012. A note on the frequency of gastric ulcers detected during post-mortem examination at a pig abattoir. Meat Sci. 90, 269-271.

Taylor, D. J., 2006. Pig diseases (eighth edition). St Edmundsbury Press Ltd, Bury St. Edmonds. 
Thomson J. R., Friendship R. M., 2012. Digestive System, in: Zimmerman J., Karriker L., Ramirez, A., Schwartz, K. (Eds.), Diseases of Swine, Tenth Edition, Stevenson G. John Wiley and Sons, Hoboken, pp. 199-226.

Traub, R. J., Wang, G., 2004. Colonic inflammation decreases thermal sensitivity of the forepaw and hindpaw in the rat. Neurosci. Lett. 359, 81-84.

Ulens, T., Demeyer, P., Ampe, B., Van Langenhove, H., Millet, S., 2015. Effect of grinding intensity and pelleting of the diet on indoor particulate matter concentrations and growth performance of weanling pigs. J. Anim. Sci. 93, 627-636.

Visscher, C. F., Winter, P., Verspohl, J., Stratmann-Selke, J., Upmann, M. \& Beyerbach, M., Kamphues, J., 2009. Effects of feed particle size at dietary presence of added organic acids on caecal parameters and the prevalence of Salmonella in fattening pigs on farm and at slaughter. J. Anim. Physiol. An. N. 93, 423-430.

Wondra, K. J., Hancock, J. D., Behnke, K. C., Hines, R. H., Stark, C. R., 1995. Effects of particle size and pelleting on growth performance, nutrient digestibility and stomach morphology in finishing pigs. J. Anim. Sci. 73, 757-763.

Yarushkina, N., Bogdanov, A., Filaretova, L., 2006. Somatic pain sensitivity during formation and healing of acetic acid-induced gastric ulcers in conscious rats. Auton. Neurosci. 126-127, 100-105.

Zhang, M-M., Liu, S-B., Chen, T., Koga, K., Zhang, T., Li, Y-Q., Zhuo, M., 2014. Effects of NB001 and gabapentin on irritable bowel syndrome-induced behavioral anxiety and spontaneous pain. Mol. Brain 7: 47 


\section{Table 1}

Description of gastric ulcer score system ${ }^{\#}$

\begin{tabular}{|c|c|c|c|c|c|}
\hline $\begin{array}{l}\text { Gastric } \\
\text { score: }\end{array}$ & Description & $\begin{array}{l}\text { Keratosis } \\
\text { score }\end{array}$ & $\begin{array}{c}\text { Erosion } \\
\text { score }\end{array}$ & $\begin{array}{l}\text { Ulcer } \\
\text { score }\end{array}$ & $\begin{array}{l}\text { Scar } \\
\text { score }\end{array}$ \\
\hline $\mathbf{0}$ & Normal stomach with a white and shiny pars oesophagea without visible lesions & & & & \\
\hline 1 & Finely granulated parakeratosis in pars oesophagea, less than $1 \mathrm{~mm}$ thick & 1 & & & \\
\hline 2 & Coarse parakeratosis in pars oesophagea, $1-3 \mathrm{~mm}$ thick & 2 & & & \\
\hline 3 & Coarse, laciniated or papillomatous parakeratosis in pars oesophagea, more than $3 \mathrm{~mm}$ thick & 3 & & & \\
\hline 4 & $\begin{array}{l}\text { Erosion (superficial tissue erosion without damage of nerves and blood vessels) with a diameter less than } 0.5 \mathrm{~cm} \text { in pars } \\
\text { oesophagea }\end{array}$ & & 1 & & \\
\hline 5 & Erosion with a diameter on $0.5 \mathrm{~cm}$ or more in pars oesophagea & & $2 / 3$ & & \\
\hline 6 & $\begin{array}{l}\text { Superficial ulceration (nerves and blood vessels exposed and potentially damaged) with a diameter of less than } 0.5 \mathrm{~cm} \\
\text { in pars oesophagea OR palpable scar tissue in pars oesophagea consisting of one or more peripheral fibrous strands }\end{array}$ & & & 1 & 1 \\
\hline 7 & $\begin{array}{l}\text { Deep ulcers with a diameter of less than } 0.5 \mathrm{~cm} \text { or more superficial ulceration with a diameter on } 0.5-2.0 \mathrm{~cm} \text { in pars } \\
\text { oesophagea } \mathbf{O R} \text { palpable scar tissue in pars oesophagea with fibrous strands producing an almost complete circular } \\
\text { structure that may be slightly flexible }\end{array}$ & & & 2 & 2 \\
\hline 8 & $\begin{array}{l}\text { Deep ulcers with a diameter of at least } 0.5 \mathrm{~cm} \text { or more superficial ulceration with a diameter of more than } 2 \mathrm{~cm} \text { in pars } \\
\text { oesophagea } \mathbf{O R} \text { palpable scar tissue in pars oesophagea with fibrous strands producing a circular, rigid structure }\end{array}$ & & & 3 & 3 \\
\hline $9 / 10$ & $\begin{array}{l}\text { Scar tissue constricting the oesophageal opening, leaving it inflexible with a diameter between } 6 \text { and } 15 \mathrm{~mm} \text { (score 9) } \\
\text { or with a diameter of maximum } 5.9 \mathrm{~mm} \text { (score 10) }\end{array}$ & & & & \\
\hline
\end{tabular}

\# Jensen et al. 2017 


\section{Table 2}

Ethogram of recorded behaviours

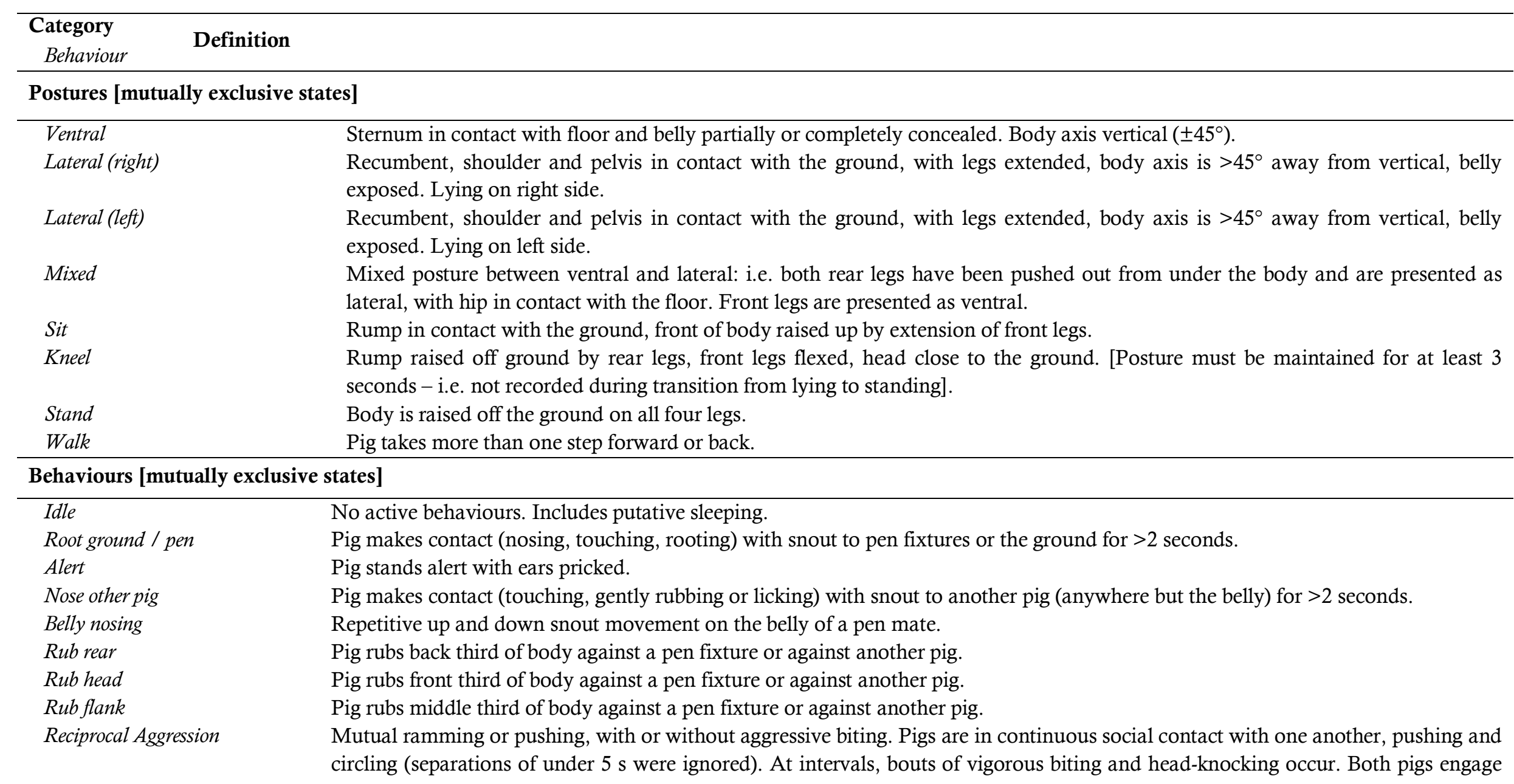


Snap

Being snapped at

Being belly nosed

Nosing rear

Ear biting

Mounting

In feeder* with the other, each apparently trying to injure the other.

In response to physical contact, usually in the form of nosing, rubbing or biting of tail, ears, flank or feet, from another pig, (may also be directed at a pig who is just walking by), focal pig reacts with a sharp movement of its head towards the head/neck of other pig.

Pig is snapped by other pig.

Pig is belly nosed by another pig.

Pig makes contact (touching, gently rubbing or licking) with snout to another pig's rear (anywhere but the belly) for $>2$ seconds.

Taking the ear of a pen mate into the mouth or nibbling, sucking or chewing the ear.

Pig lifts its two front legs and puts the two legs or its breast on any part of the body or head of another pig.

GR: At least head and front two legs are over the threshold of the automatic feeder.

EH: Head in feed trough.

\section{Behavioural Events}

Ease quarters hind limbs

Ease quarters front limbs

Back leg forward

Kick

Leg twitch

Draw in back leg

Paw

Back arch

Whole body movement (shudder)
One or both rear legs gently shifted in position (tensed and relaxed) in a less forceful manner than kicking.

One or both front legs gently shifted in position (tensed and relaxed) in a less forceful manner than kicking.

One or both rear legs brought rapidly forward towards abdomen and then returned to original position.

One or both rear legs rapidly pushed out and away from body.

One or both rear legs shows brief sharp movement, but doesn't change position.

In a lateral lying position, the back leg is pulled in towards the body in a lower less forceful manner than kicking.

In a lateral lying position, one or both front legs moved forward and away from the body and dragged back.

In a lateral lying position, one or both sets of legs become tense and are pushed away from the body and/or inwards towards the centre, forming an arch in the back.

Whole body movement (when lying) that does not result in a shift to a new posture.

* Due to the different feeder set-ups at the two farms, the definition for being in the feeder varied. 

Livestock Science by Elsevier

For more articles on animal ethics, see www.animalethics.net

Table 3

Frequency (and percentage) of pigs with different gastric ulcer scores across different experimental batches at research farms in Denmark (GR) and Scotland (EH).

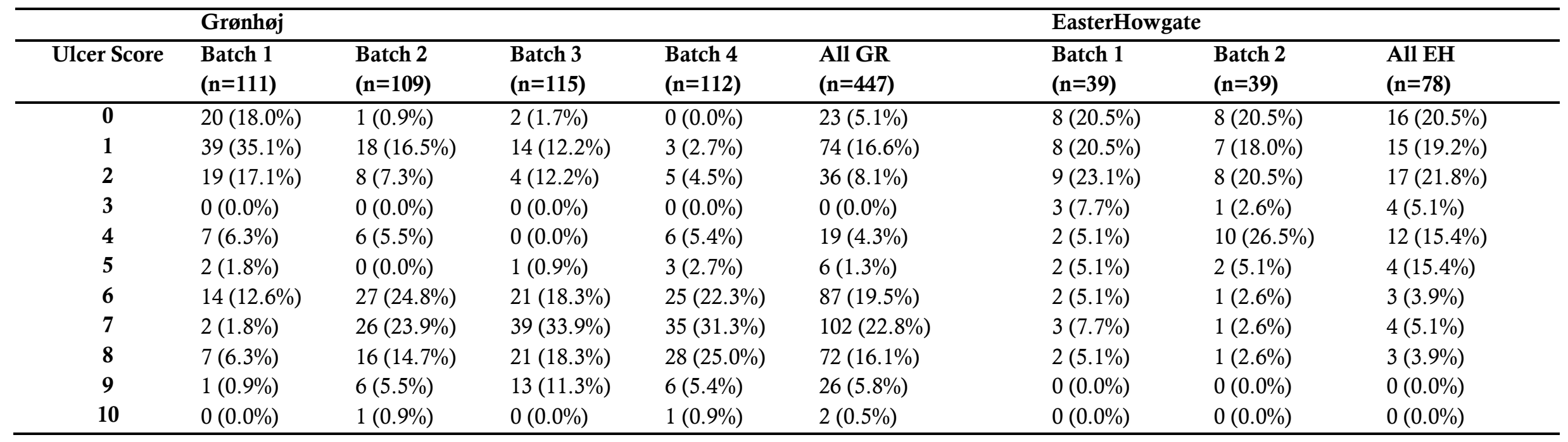




\section{Table 4}

Predicted means and statistical analysis for postures of pigs observed at research farms in Denmark (Grønhøj) and Scotland (EasterHowgate) and for a combined data set. Significant findings $(\mathrm{P}<0.05)$ are highlighted in bold.

\begin{tabular}{|c|c|c|c|c|c|c|c|c|c|c|c|}
\hline & \multicolumn{3}{|c|}{ Grønhøj } & \multicolumn{3}{|c|}{ EasterHowgate } & \multicolumn{5}{|c|}{ Combined } \\
\hline & $\begin{array}{l}\text { Ulcer } \\
(n=19)\end{array}$ & $\begin{array}{l}\text { Healthy } \\
(n=21)\end{array}$ & Ulcer Status & $\begin{array}{l}\text { Ulcer } \\
(n=7)\end{array}$ & $\begin{array}{l}\text { Healthy } \\
(n=15)\end{array}$ & Ulcer Status & Ulcer & Healthy & Site & $\begin{array}{l}\text { Ulcer } \\
\text { Status }\end{array}$ & $\begin{array}{l}\text { Site by } \\
\text { Status }\end{array}$ \\
\hline $\begin{array}{r}\text { Category } \\
\text { Variable }\end{array}$ & $\begin{array}{l}\text { Mean } \\
(\mathrm{SE})\end{array}$ & $\begin{array}{l}\text { Mean } \\
(\mathrm{SE})\end{array}$ & $\begin{array}{l}\text { P value } \\
\text { (F value) }\end{array}$ & $\begin{array}{l}\text { Mean } \\
(\mathrm{SE})\end{array}$ & $\begin{array}{l}\text { Mean } \\
(\mathrm{SE})\end{array}$ & $\begin{array}{l}\mathrm{P} \text { value } \\
\text { (F value) }\end{array}$ & $\begin{array}{l}\text { Mean } \\
(\mathrm{SE})\end{array}$ & $\begin{array}{l}\text { Mean } \\
(\mathrm{SE})\end{array}$ & $\begin{array}{l}\mathrm{P} \text { value } \\
\text { ( } \mathrm{F} \text { value) }\end{array}$ & $\begin{array}{l}\mathrm{P} \text { value } \\
\text { ( } \mathrm{F} \text { value })\end{array}$ & $\begin{array}{l}\mathrm{P} \text { value } \\
\text { ( } \mathrm{F} \text { value) }\end{array}$ \\
\hline \multicolumn{12}{|l|}{ Postures (duration, secs) } \\
\hline Lateral left & $\begin{array}{l}1389 \\
(343)\end{array}$ & $\begin{array}{l}1946 \\
(220)\end{array}$ & $\begin{array}{l}0.217 \\
(1.52)\end{array}$ & $\begin{array}{l}1187 \\
(425)\end{array}$ & $\begin{array}{l}2442 \\
(302)\end{array}$ & $\begin{array}{l}0.044 \\
(5.18)\end{array}$ & $\begin{array}{l}1416 \\
(303)\end{array}$ & $\begin{array}{l}2132 \\
(216)\end{array}$ & $\begin{array}{l}0.492 \\
(0.49)\end{array}$ & $\begin{array}{l}0.064 \\
(3.76)\end{array}$ & $\begin{array}{l}0.489 \\
(0.48)\end{array}$ \\
\hline Lateral right) & $\begin{array}{l}1712 \\
(372)\end{array}$ & $\begin{array}{l}1736 \\
(380)\end{array}$ & $\begin{array}{l}0.960 \\
(0.00)\end{array}$ & $\begin{array}{l}1671 \\
(262)\end{array}$ & $\begin{array}{l}1660 \\
(359)\end{array}$ & $\begin{array}{l}0.981 \\
(0.00)\end{array}$ & $\begin{array}{l}2010 \\
(319)\end{array}$ & $\begin{array}{l}1958 \\
(273)\end{array}$ & $\begin{array}{l}0.252 \\
(1.37)\end{array}$ & $\begin{array}{l}0.895 \\
(0.02)\end{array}$ & $\begin{array}{l}0.773 \\
(0.08)\end{array}$ \\
\hline Ventral & $\begin{array}{l}1525 \\
(218)\end{array}$ & $\begin{array}{l}1110 \\
(219)\end{array}$ & $\begin{array}{l}0.162 \\
(2.03)\end{array}$ & $\begin{array}{l}1135 \\
(317)\end{array}$ & $\begin{array}{l}1501 \\
(220)\end{array}$ & $\begin{array}{l}0.374 \\
(0.84)\end{array}$ & $\begin{array}{l}1461 \\
(198)\end{array}$ & $\begin{array}{l}1308 \\
(164)\end{array}$ & $\begin{array}{l}0.553 \\
(0.36)\end{array}$ & $\begin{array}{l}0.541 \\
(0.38)\end{array}$ & $\begin{array}{l}0.080 \\
(3.19)\end{array}$ \\
\hline Mixed & $\begin{array}{l}354 \\
(152)\end{array}$ & $\begin{array}{l}690 \\
(151)\end{array}$ & $\begin{array}{l}0.108 \\
(2.72)\end{array}$ & $\begin{array}{l}481 \\
(170)\end{array}$ & $\begin{array}{l}201 \\
(116)\end{array}$ & $\begin{array}{l}0.186 \\
(1.88)\end{array}$ & $\begin{array}{l}322 \\
(124)\end{array}$ & $\begin{array}{l}455 \\
(105)\end{array}$ & $\begin{array}{l}0.133 \\
(2.36)\end{array}$ & $\begin{array}{l}0.395 \\
(0.73)\end{array}$ & $\begin{array}{l}0.062 \\
(3.64)\end{array}$ \\
\hline Kneel/Sit) & $\begin{array}{l}185 \\
(60)\end{array}$ & $\begin{array}{l}72 \\
(26)\end{array}$ & $\begin{array}{l}0.07 \\
(3.51)\end{array}$ & $\begin{array}{l}128 \\
(59)\end{array}$ & $\begin{array}{l}119 \\
(41)\end{array}$ & $\begin{array}{l}0.902 \\
(0.02)\end{array}$ & $\begin{array}{l}233 \\
(55)\end{array}$ & $\begin{array}{l}172 \\
(46)\end{array}$ & $\begin{array}{l}0.05 \\
(4.18)\end{array}$ & $\begin{array}{l}0.374 \\
(0.80)\end{array}$ & $\begin{array}{l}0.511 \\
(0.44)\end{array}$ \\
\hline Stand & $\begin{array}{l}1630 \\
(242)\end{array}$ & $\begin{array}{l}1143 \\
(240)\end{array}$ & $\begin{array}{l}0.147 \\
(2.20)\end{array}$ & $\begin{array}{l}1399 \\
(205)\end{array}$ & $\begin{array}{l}728 \\
(157)\end{array}$ & $\begin{array}{l}0.009 \\
(10.65)\end{array}$ & $\begin{array}{l}155 \\
(188)\end{array}$ & $\begin{array}{l}925 \\
(158)\end{array}$ & $\begin{array}{l}0.281 \\
(1.20)\end{array}$ & $\begin{array}{l}0.009 \\
(7.24)\end{array}$ & $\begin{array}{l}0.423 \\
(0.65)\end{array}$ \\
\hline Walking & $\begin{array}{l}71 \\
(13)\end{array}$ & $\begin{array}{l}47 \\
(13)\end{array}$ & $\begin{array}{l}0.133 \\
(2.35)\end{array}$ & $\begin{array}{l}67 \\
(19)\end{array}$ & $\begin{array}{l}39 \\
(13)\end{array}$ & $\begin{array}{l}0.221 \\
(1.61)\end{array}$ & $\begin{array}{l}70 \\
(11)\end{array}$ & $\begin{array}{l}43 \\
(10)\end{array}$ & $\begin{array}{l}0.749 \\
(0.10)\end{array}$ & $\begin{array}{l}0.038 \\
(4.52)\end{array}$ & $\begin{array}{l}0.864 \\
(0.03)\end{array}$ \\
\hline $\begin{array}{l}\text { Total Posture changes } \\
\text { (number) }\end{array}$ & $\begin{array}{l}66 \\
(8) \\
\end{array}$ & $\begin{array}{l}54 \\
(8)\end{array}$ & $\begin{array}{l}0.323 \\
(1.00)\end{array}$ & $\begin{array}{l}61 \\
(13)\end{array}$ & $\begin{array}{l}41 \\
(9)\end{array}$ & $\begin{array}{l}0.189 \\
(1.88)\end{array}$ & $\begin{array}{l}67 \\
(8)\end{array}$ & $\begin{array}{l}45 \\
(7)\end{array}$ & $\begin{array}{l}0.688 \\
(0.16)\end{array}$ & $\begin{array}{l}0.022 \\
(5.57)\end{array}$ & $\begin{array}{l}0.523 \\
(0.41)\end{array}$ \\
\hline
\end{tabular}

${ }^{*}$ EH: data back transformed $(\log 10)$

${ }^{\#}$ GR: data back transformed $(\log 10)$ 


\section{Table 5}

Predicted means and statistical analysis for behavioural states and events of pigs observed at research farms in Denmark (Grønhøj) and Scotland (EasterHowgate) and for a combined data set. Significant findings $(\mathrm{P}<0.05)$ are highlighted in bold.

\begin{tabular}{|c|c|c|c|c|c|c|c|c|c|c|c|}
\hline & Grønhøj & & & Easter & Howgate & & Combi & ned & & & \\
\hline & $\begin{array}{l}\text { Ulcer } \\
(n=19)\end{array}$ & $\begin{array}{l}\text { Healthy } \\
(n=21)\end{array}$ & $\begin{array}{l}\text { Ulcer } \\
\text { Status }\end{array}$ & $\begin{array}{l}\text { Ulcer } \\
(n=7)\end{array}$ & $\begin{array}{l}\text { Healthy } \\
(n=15)\end{array}$ & $\begin{array}{l}\text { Ulcer } \\
\text { Status }\end{array}$ & Ulcer & Healthy & Site & $\begin{array}{l}\text { Ulcer } \\
\text { Status }\end{array}$ & $\begin{array}{l}\text { Site by } \\
\text { Status }\end{array}$ \\
\hline $\begin{array}{r}\text { Category } \\
\text { Variable }\end{array}$ & $\begin{array}{l}\text { Mean } \\
(\mathrm{SE})\end{array}$ & $\begin{array}{l}\text { Mean } \\
(\mathrm{SE})\end{array}$ & $\begin{array}{l}\mathrm{P} \text { value } \\
\text { ( } \mathrm{F} \text { value) }\end{array}$ & $\begin{array}{l}\text { Mean } \\
(\mathrm{SE})\end{array}$ & $\begin{array}{l}\text { Mean } \\
(\mathrm{SE})\end{array}$ & $\begin{array}{l}\mathrm{P} \text { value } \\
\text { ( } \mathrm{F} \text { value) }\end{array}$ & $\begin{array}{l}\text { Mean } \\
(\mathrm{SE})\end{array}$ & $\begin{array}{l}\text { Mean } \\
(\mathrm{SE})\end{array}$ & $\begin{array}{l}\mathrm{P} \text { value } \\
\text { ( } \mathrm{F} \text { value) }\end{array}$ & $\begin{array}{l}\mathrm{P} \text { value } \\
\text { (F value) }\end{array}$ & $\begin{array}{l}\mathrm{P} \text { value } \\
\text { (F value) }\end{array}$ \\
\hline \multicolumn{12}{|c|}{ States (duration, secs) } \\
\hline Feeder & $\begin{array}{l}753 \\
(165)\end{array}$ & $\begin{array}{l}532 \\
(154)\end{array}$ & $\begin{array}{l}0.341 \\
(0.94)\end{array}$ & $\begin{array}{l}358 \\
(104)\end{array}$ & $\begin{array}{l}257 \\
(71)\end{array}$ & $\begin{array}{l}0.416 \\
(0.69)\end{array}$ & $\begin{array}{l}587 \\
(124)\end{array}$ & $\begin{array}{l}394 \\
(100)\end{array}$ & $\begin{array}{l}0.069 \\
(3.54)\end{array}$ & $\begin{array}{l}0.223 \\
(1.52)\end{array}$ & $\begin{array}{l}0.790 \\
(0.07)\end{array}$ \\
\hline Idle & $\begin{array}{l}5500 \\
(268)\end{array}$ & $\begin{array}{l}5902 \\
(220)\end{array}$ & $\begin{array}{l}0.284 \\
(1.20)\end{array}$ & $\begin{array}{l}5528 \\
(337)\end{array}$ & $\begin{array}{l}6005 \\
(243)\end{array}$ & $\begin{array}{l}0.217 \\
(1.66)\end{array}$ & $\begin{array}{l}5434 \\
(227)\end{array}$ & $\begin{array}{l}5945 \\
(181)\end{array}$ & $\begin{array}{l}0.805 \\
(0.06)\end{array}$ & $\begin{array}{l}0.081 \\
(3.18)\end{array}$ & $\begin{array}{l}0.739 \\
(0.11)\end{array}$ \\
\hline Nose & $\begin{array}{l}339 \\
(136)\end{array}$ & $\begin{array}{l}43 \\
(134)\end{array}$ & $\begin{array}{l}0.097 \\
(2.9)\end{array}$ & $\begin{array}{l}49 \\
(33)\end{array}$ & $\begin{array}{l}61 \\
(24)\end{array}$ & $\begin{array}{l}0.73 \\
(0.12)\end{array}$ & $\begin{array}{l}240 \\
(93)\end{array}$ & $\begin{array}{l}54 \\
(79)\end{array}$ & $\begin{array}{l}0.452 \\
(0.58)\end{array}$ & $\begin{array}{l}0.114 \\
(2.57)\end{array}$ & $\begin{array}{l}0.321 \\
(1.00)\end{array}$ \\
\hline Root/Explore & $\begin{array}{l}37 \\
(28)\end{array}$ & $\begin{array}{l}38.8 \\
(25.9)\end{array}$ & $\begin{array}{l}0.971 \\
(0.00)\end{array}$ & $\begin{array}{l}1130 \\
(273)\end{array}$ & $\begin{array}{l}682 \\
(188)\end{array}$ & $\begin{array}{l}0.179 \\
(1.94)\end{array}$ & $\begin{array}{l}507 \\
(98.7)\end{array}$ & $\begin{array}{l}356 \\
(89.0)\end{array}$ & $\begin{array}{l}<0.001 \\
(26.5)\end{array}$ & $\begin{array}{l}0.161 \\
(2.02)\end{array}$ & $\begin{array}{l}0.052 \\
(3.94)\end{array}$ \\
\hline \multicolumn{12}{|c|}{ Events (freq. $/ 2 h r s$ ) } \\
\hline$B A C K L E G$ & $\begin{array}{l}95.6 \\
(16.3)\end{array}$ & $\begin{array}{l}88.4 \\
(16.6)\end{array}$ & $\begin{array}{l}0.732 \\
(0.12)\end{array}$ & $\begin{array}{l}80.3 \\
(12.9)\end{array}$ & $\begin{array}{l}66.8 \\
(10.0)\end{array}$ & $\begin{array}{l}0.417 \\
(0.68)\end{array}$ & $\begin{array}{l}86.7 \\
(11.5)\end{array}$ & $\begin{array}{l}77.4 \\
(10.2)\end{array}$ & $\begin{array}{l}0.225 \\
(1.53)\end{array}$ & $\begin{array}{l}0.522 \\
(0.42)\end{array}$ & $\begin{array}{l}0.861 \\
(0.03)\end{array}$ \\
\hline FRONT LEG & $\begin{array}{l}11.1 \\
(3.7)\end{array}$ & $\begin{array}{l}10.6 \\
(3.5)\end{array}$ & $\begin{array}{l}0.912 \\
(0.01)\end{array}$ & $\begin{array}{l}9.7 \\
(3.2)\end{array}$ & $\begin{array}{l}6.7 \\
(1.7)\end{array}$ & $\begin{array}{l}0.395 \\
(0.76)\end{array}$ & $\begin{array}{l}10.3 \\
(2.6)\end{array}$ & $\begin{array}{l}8.5 \\
(1.8)\end{array}$ & $\begin{array}{l}0.374 \\
(0.82)\end{array}$ & $\begin{array}{l}0.556 \\
(0.35)\end{array}$ & $\begin{array}{l}0.581 \\
(0.31)\end{array}$ \\
\hline TOTAL & $\begin{array}{l}127.4 \\
(21.2)\end{array}$ & $\begin{array}{l}124.8 \\
(21.7)\end{array}$ & $\begin{array}{l}0.926 \\
(0.01)\end{array}$ & $\begin{array}{l}99.6 \\
(13.9)\end{array}$ & $\begin{array}{l}87.1 \\
(10.8)\end{array}$ & $\begin{array}{l}0.488 \\
(0.50)\end{array}$ & $\begin{array}{l}112.2 \\
(14.5)\end{array}$ & $\begin{array}{l}105.4 \\
(12.9)\end{array}$ & $\begin{array}{l}0.104 \\
(2.82)\end{array}$ & $\begin{array}{l}0.712 \\
(0.14)\end{array}$ & $\begin{array}{l}0.812 \\
(0.06)\end{array}$ \\
\hline
\end{tabular}

\# EH, GR and combined: data back transformed $(\log 10)$ 